\title{
Penggunaan Media Peta Berbasis Web untuk Pembelajaran Geografi SMA
}

\author{
Diah Wijayanti ${ }^{1}$, I Komang Astina ${ }^{1}$, Syamsul Bachri ${ }^{1}$ \\ ${ }^{1}$ Pendidikan Geografi-Universitas Negeri Malang
}

\begin{tabular}{l} 
INFO ARTIKEL \\
\hline Riwayat Artikel: \\
Diterima: 06-05-2019 \\
Disetujui: 25-05-2019 \\
\hline
\end{tabular}

Kata kunci:

learning media; web based map geography; media pembelajaran; peta berbasis web; geografi

\begin{abstract}
ABSTRAK
Abstract: This study aims to produce web-based map learning media and determine the level of media effectiveness in geography subjects in class XI IPS. This research is a research and development that tends to produce products. The resulting product is a web-based map learning media. The instrument used was a questionnaire. This research was conducted with the ADDIE development model. The validation test results are $75 \%$, meaning the media is valid and can be tested. The results of student trials reached a score of $80 \%$ and the results of teacher trials reached a score of $83.3 \%$. The trial results indicate an effective level, meaning the media is suitable to be used.
\end{abstract}

\begin{abstract}
Abstrak: Penelitian ini bertujuan untuk menghasilkan media pembelajaran peta berbasis web dan mengetahui tingkat keefektifan media pada mata pelajaran Geografi kelas XI IPS. Penelitian ini merupakan research and development yang berkecendurungan menghasilkan produk. Produk yang dihasilkan berupa media pembelajaran peta berbasis web. Instrumen yang digunakan adalah angket. Penelitian ini dilakukan dengan model pengembangan ADDIE. Hasil uji validasi sebesar 75\%, berarti media valid dan dapat dilakukan uji coba. Hasil uji coba siswa mencapai skor $80 \%$ dan hasil uji coba guru mencapai skor $83,3 \%$. Hasil uji coba menunjukkan tingkat efektif, berarti media layak dipergunakan.
\end{abstract}

\author{
Alamat Korespondensi: \\ Diah Wijayanti \\ Pendidikan Geografi \\ Universitas Negeri Malang \\ Jalan Semarang 5 Malang \\ E-mail: diahwijayanti89952@gmail.com
}

Pembelajaran Geografi membutuhkan media yang dapat mendorong siswa untuk belajar. Media berguna untuk mengarahkan informasi yang berada di dalamnya dan melibatkan siswa dalam pikiran maupun psikologisnya, serta kegiatan nyata sehingga terjadi pembelajaran (Arsyad, 2013). Media memuat materi pembelajaran sehingga siswa dapat memanfaatkan untuk belajar sehingga mendapatkan wawasan, keterampilan, dan afektif yang baik (Suryani, 2016). Hal tersebut berarti bahwa media berisi informasi yang mengontruksi kognitif, sikap, dan psikomotorik siswa. Media pembelajaran yang variatif bisa menarik siswa. Sejalan dengan pernyataan tersebut, (Nadlah, 2011) menyimpulkan bahwa, "media pembelajaran yang bervariasi dapat meningkatkan kualitas pembelajaran materi pada siswa. Hasil belajar seseorang mulai dari pengalaman langsung (konkret), kenyataan yang ada di lingkungan kehidupan seseorang mulai dari benda tiruan, sampai kepada lambang verbal atau abstrak Dale tahun 1969 dalam (Arsyad, 2013). Pendapat tersebut menguatkan bahwa fungsi utama dari peta adalah dapat menjawab setiap pertanyaan yang terdapat dalam geografi, memperoleh informasi tentang sumberdaya, mengeksplor data geografi, menganalisis informasi geografi, dan menambah pengetahuan geografi di masa mendatang.

Peta dapat membantu dalam mengetahui bagaimana keterkaitan berbagai fenomena yang dipelajari serta menimbulkan fenomena berbeda ataupun baru. Penggunaan media peta (termasuk peta tematik) akan memberikan gambaran yang lebih jelas dan pengertian kognisi yang membantu dalam kelancaran belajar siswa (Yusuf, Yarmaidi, \& Miswar, 2015). Oleh karena itu, pentingnya suatu media pembelajaran untuk menunjang maupun meningkatkan segala aktivitas dan hasil belajar siswa. Peta sebagai media pembelajaran Geografi dapat dipermudah dalam mengakses dengan adanya internet. Media pembelajaran yang sangat berpengaruh dan sangat dekat dengan para remaja atau peserta didik saat ini adalah internet (Sari \& Suswanto, 2017). Internet dapat diakses dan dimanfaatkan oleh semua orang, di tempat manapun, dan waktu kapanpun.

Berdasarkan hasil observasi dan wawancara pada 15 November 2018 kepada siswa kelas XI IPS SMAN 1 Srono dan SMAN 1 Cluring Kab. Banyuwangi, beberapa siswa mengungkapkan bahwa mereka tidak menggunakan media pembelajaran geografi seperti peta, citra, maupun Sistem Informasi Geografis (SIG) dalam pembelajaran. Siswa hanya menggunakan media peta umum maupun peta yang ada di internet. Penggunaan peta umum maupun peta tematik yang ada di internet pun hanya pada beberapa materi pembelajaran. Hal lainya, mengenai penguasaan teknologi informasi dan komunikasi serta penguasaan teknologi mengenai media geografi (sistem informasi geografi, citra, gps, dll) masih kurang. 
Media peta yang ada belum membantu siswa dalam pembelajaran Geografi. Penyebabnya terletak pada penyajian peta yang masih umum, isi belum kontekstual, sebagaimana yang diungkapkan De Porter tahun 2000 (Utomo, 2015) yakni membawa dunia mereka ke dunia kita, dan membawa dunia kita ke dunia mereka. Media berbasis kontekstual akan membuat siswa belajar lebih bermakna (Sulfiah \& Sulisworo, 2016). Pengembangan media ini juga berdasarkan hasil penelitian (Wahyuningsih \& Budiningsih, 2013) menyimpulkan bahwa pengembangan media dalam pembelajaran IPS bahwa kelas yang menggunakan media ajar lebih baik dari pada kelas yang tidak menggunakan media ajar dan hanya menggunakan metode ceramah saja.

Penelitian dan pengembangan media peta yang berbasis web lebih memudahkan siswa dalam mencari informasi. Rusman tahun 2013 dalam (Putri, Corebima, \& Lestari, 2016) bahwa keuntungan penggunaan web yaitu pebelajar dapat belajar sesuai dengan karakteristik dan langkahnya dirinya sendiri karena pembelajaran berbasis web dapat dilakukan baik di dalam maupun luar lingkungan belajar. Pengembangan penting dilakukan guru agar kualitas pembelajaran baik serta menunjukkan profesionalisme guru saat membuat bahan ajar maupun media pembelajaran sendiri (Evendy, Sumarmi, \& Astina, 2018). Alasan pentingnya mengembangkan media pembelajaran yakni keberadaan terbatas dan manfaat media.

Media pembelajaran berbasis web dapat meningkatkan semangat belajar siswa. Pemilihan media pembelajaran web sendiri tidak terlepas dari pendapat Boulton \& Trent tahun 2008 dalam (Widiyaningtyas \& Widiatmoko, 2014) yang mengatakan bahwa, siswa yang memiliki kemampuan rendah dalam kognitif dapat diatasi dengan memberikan media yang berbasis web sebagai tambahan atau dukungan pembelajaran. Penggunaan media pembelajaran berbasis web akan mempermudah siswa dalam belajar karena siswa milenial kini lebih menyukai teknologi atau membaca melalui media di internet.

Tujuan dari penelitian ini adalah menghasilkan produk berupa media pembelajaran peta yang berbasis web untuk mata pelajaran geografi SMA kelas XI IPS di Banyuwangi, dan untuk melihat tingkat efektivitas produk dalam pembelajaran. Media pembelajaran ini diharapkan dapat menunjang pembelajaran sehingga mempermudah siswa dalam memahami materi pelajaran yang disajikan guru di kelas.

\section{METODE}

Penelitian ini merupakan Research and Development. Model penelitian dan pengembangan yang digunakan yaitu ADDIE (Analysis, Design, Development or Production, Implementation or Delivery and Evaluations). Sarana (instrumen) yang digunakan untuk pengolahan penelitian ini adalah angket. Angket merupakan teknik untuk memperoleh data mengenai semua hal berkaitan dengan ketercapaian media pembelajaran. Angket diberikan kepada responden (validator, siswa, dan guru) untuk mendapatkan penilaian yang otentik terkait produk.

Bentuk angket dalam penelitian ini berisi beberapa pernyataan yang dapat menjadi acuan untuk melakukan perbaikan. (1) angket berupa uraian perbaikan dari ahli bidang studi dan ahli desain pembelajaran yang berupa hasil uraian validator, diskusi, dan konsultasi digunakan untuk merevisi produk; (2) angket uji coba lapangan yang bertujuan untuk menilai fungsi gambar, teks, warna, dan fungsi keberadaan media pembelajaran tersebut.

Teknik analisis data yang dipergunakan dalam penelitian dan pengembangan ini yaitu analisis kuantitatif. Analisis data kuantitatif digunakan untuk mengolah data yang diperoleh dalam bentuk analisis persentase dari angket hasil uji coba. Selanjutnya, diinterpretasikan dengan kalimat yang bersifat deskriptif. Rumus yang digunakan untuk menganalisis data berupa:

Keterangan:

$$
\mathrm{P}=\frac{\Sigma x}{\Sigma x i} \times 100 \%
$$

$\begin{array}{ll}P & =\text { Persentase } \\ \Sigma x & =\text { Jumlah skor jawaban respinden } \\ \Sigma x i & =\text { Jumlah skor maksimal } \\ 100 & =\text { Konstanta }\end{array}$

Jumlah persentase minimum yang harus diperoleh pengembangan media pembelajaran sesuai dengan kriteria tersebut adalah $71 \%$. Media pembelajaran sudah bisa dimanfaatkan atau digunakan dalam pembelajaran. jika hasil perolehan persentase $\leq 71 \%$, maka produk media pembelajaran harus dilakukan revisi terlebih dahulu.

\section{HASIL}

Data analisis keefektifan produk diperoleh dari angket guru dan siswa pada uji coba lapangan, selanjutnya dianalisis menggunakan rumus. Hasil dari data keefektifan dikonversikan ke dalam tabel 1 konversi tingkat keefektifan produk. Sebelum dilakukan uji coba media, tahap awal yakni validasi produk kepada ahli media.

Berdasarkan tabel 1 hasil validasi ahli media diperoleh nilai kevalidan sebesar $75 \%$ dengan kriteria tingkat kevalidan produk yaitu "valid". Berdasarkan nilai validasi dari ahli media tersebut dapat dirata-rata yaitu 75\%. Jika dikonversikan pada tingkat kevalidan produk maka memenuhi kriteria "valid". 
Hasil yang diperoleh pada uji coba yaitu data angket guru dan siswa. Pernyataan dalam angket memiliki poin dan setiap poin memiliki skor 1-4. Skor-skor tersebut memiliki keterangan, yaitu (a) Skor 4, jika sangat setuju/sangat sesuai/sangat menarik/sangat baik, (b) Skor 3, jika setuju/sesuai/menarik/baik, (c) Skor 2, jika cukup setuju/ cukup sesuai/ cukup menarik/ cukup baik, dan (d) Skor 1, jika tidak setuju/ tidak sesuai/tidak menarik/ tidak baik. Hasil dari uji coba oleh guru dapat dilihat pada tabel 2.

Tabel 1. Rekapitulasi Hasil Analisis Data Kevalidan Produk

\begin{tabular}{clcl}
\hline No & Validasi & Nilai & Keterangan \\
\hline 1. & Ahli Media & $75 \%$ & Valid \\
\cline { 1 - 2 } & Total Persentase & \multirow{2}{*}{$75 \%$} & \\
\cline { 2 - 3 } & Rata-rata Persentase & \\
\hline
\end{tabular}

Tabel 2. Data Angket Uji Coba pada Guru

\begin{tabular}{|c|c|c|c|c|c|}
\hline \multirow{2}{*}{ No } & \multirow{2}{*}{ Aspek yang dinilai } & \multicolumn{3}{|c|}{ Skor } & \multirow[t]{2}{*}{ Komentar } \\
\hline & & 1 & 2 & 3 & \\
\hline & Petunjuk penggunaan mudah dipahami & & & $\sqrt{ }$ & \\
\hline 1 & Media peta mudah digunakan & & & $\sqrt{ }$ & \\
\hline 2 & Media peta mempermudah pencapaian tujuan pembelajaran & & $\sqrt{ }$ & & \\
\hline 3 & Media peta dapat menghemat waktu Pembelajaran & & $\sqrt{ }$ & & \\
\hline 4 & Media peta dapat meningkatkan aktivitas belajar siswa & & & & $\sqrt{ }$ \\
\hline 5 & Media peta membantu menciptakan rasa senang siswa & & & $\sqrt{ }$ & \\
\hline 6 & Media peta dapat digunakan berulang-ulang & & & $\sqrt{ }$ & \\
\hline 7 & Media peta dapat membantu siswa belajar mandiri & & $\sqrt{ }$ & & \\
\hline 8 & Media peta sesuai dengan lingkungan belajar siswa & & & & $\sqrt{ }$ \\
\hline 9 & Media peta sesuai dengan materi siswa & & & $\sqrt{ }$ & \\
\hline 10 & Media Peta & & & $\sqrt{ }$ & \\
\hline 11 & Senang dengan tampilan media & & & $\sqrt{ }$ & \\
\hline 12 & Media dapat diakses dengan mudah & & & $\sqrt{ }$ & \\
\hline 13 & Media membantu dalam pembelajaran geografi & & & $\sqrt{ }$ & \\
\hline 14 & Media Peta & & & $\sqrt{ }$ & \\
\hline 15 & Tertarik untuk mengembangkan media pada pembelajaran yang lain & & & $\sqrt{ }$ & \\
\hline
\end{tabular}

\section{Sumber: Angket Guru pada Uji Coba}

Berdasarkan tabel 2 di atas, Angket uji coba pada dua orang guru yang berisi 15 pernyataan dengan frekuensi skala 4. Berdasarkan hasil uji coba guru dengan total skor empirik yang didapatkan yaitu 50 dari skor maksimal yang diharapkan adalah 60. Adapun persentase yang didapatkan yaitu 83,33\% dengan kriteria efektif digunakan dalam pembelajaran. Adapun data hasil angket uji coba oleh siswa dijabarkan pada tabel 3.

Tabel 3. Data Angket Siswa Uji Coba pada Siswa

\begin{tabular}{|c|c|c|c|c|c|c|}
\hline \multirow{2}{*}{ No } & \multirow{2}{*}{ Indikator } & \multicolumn{4}{|c|}{ Skor } & \multirow[t]{2}{*}{ Komentar } \\
\hline & & 1 & 2 & 3 & 4 & \\
\hline 1 & Media mudah digunakan & & & $\sqrt{ }$ & & \\
\hline 2 & Materi dan bahasa mudah dipahami & & & & $\sqrt{ }$ & \\
\hline 3 & Materi mudah diingat & & & $\sqrt{ }$ & & \\
\hline 4 & Merasa mendapat pengetahuan baru & & & $\sqrt{ }$ & & \\
\hline 5 & Media mudah diakses & & & $\sqrt{ }$ & & \\
\hline 6 & Kemenarikan tampilan & & & $\sqrt{ }$ & & \\
\hline 7 & Pembelajaran dengan media menyenangkan & & & $\sqrt{ }$ & & \\
\hline 8 & Meningkatkan semangat belajar & & & $\sqrt{ }$ & & \\
\hline 9 & Senang dengan menggunakan media & & & $\sqrt{ }$ & & \\
\hline 10 & Merasa senang dengan materi di media & & & $\sqrt{ }$ & & \\
\hline
\end{tabular}

Sumber: Angket Siswa pada Uji Coba 
Berdasarkan tabel 3 di atas, angket siswa terdiri dari 10 pernyataan dengan frekuensi skala 4. Skor rata-rata yang diperoleh dari hasil angket dari kedua sekolah atau berjumlah 62 siswa yaitu:

$$
\begin{aligned}
& \mathrm{P}=\frac{32}{40} \times 100 \% \\
& \mathrm{P}=80 \%
\end{aligned}
$$

Total skor empirik yang didapatkan yaitu 32 dari skor maksimal yang diharapkan adalah 40. Persentase yang didapatkan yaitu $80.00 \%$ dengan kriteria efektif dan dapat digunakan dalam pembelajaran. Rekapitulasi hasil analisis data tingkat keefektifan dapat dilihat pada tabel 4.

\section{Tabel 4. Rekapitulasi Hasil Analisis Data Keefektifan Produk}

\begin{tabular}{clll}
\hline No & Sumber Data & Persentase & Keterangan \\
\hline 1. & Angket guru & $83,33 \%$ & Efektif \\
\hline 2. & Angket siswa & $80,00 \%$ & Efektif \\
\hline & Total Persentase & $163,33 \%$ & \\
& Rata-rata Persentase & $81,65 \%$ & \\
\hline
\end{tabular}

Berdasarkan tabel 4, persentase keefektifan yang diperoleh pada uji lapangan pada angket respons guru menunjukkan persentase $83,33 \%$ dengan kriteria tingkat kepraktisan yaitu sangat praktis dan angket respons siswa menunjukkan persentase $80 \%$ dengan kriteria tingkat keefektifan yaitu sangat efektif. Berdasarkan nilai dari angket respons guru dan siswa pada uji coba terbatas dan uji lapangan tersebut dapat dirata-ratakan yaitu $81,65 \%$. Jika persentase tersebut dikonversikan pada tingkat keefektifan produk maka memenuhi kriteria “efektif”. Berikut gambaran grafik tingkat efektivitas media, sebagaimana pada gambar 1 .

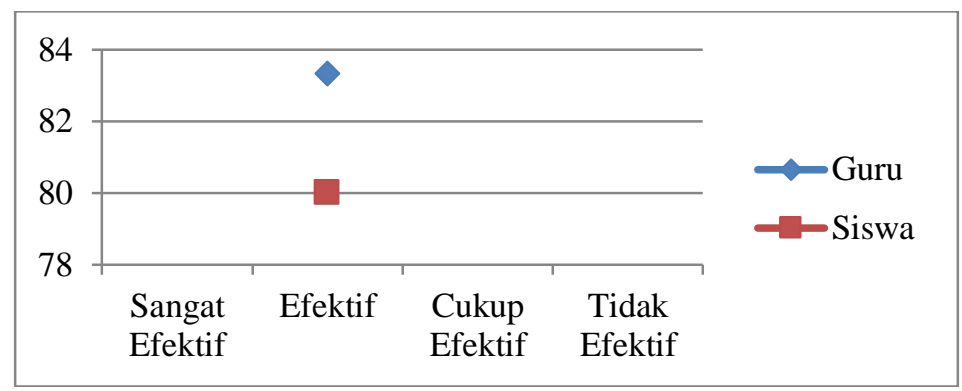

Gambar 1. Efektivitas Media Pembelajaran

\section{PEMBAHASAN}

Hasil uji coba produk di SMAN 1 Srono dan SMAN 1 Cluring Banyuwangi menunjukkan bahwa media pembelajaran peta berbasis web efektif dan dapat dimanfaatkan dalam pembelajaran Geografi. Keefektifan media pembelajaran tersebut didukung oleh hasil penskoran angket guru dan siswa. Hal ini sesuai hasil penelitian (Rahmawati, Roekhan, \& Nurchasanah, 2016) juga menyatakan agar kegiatan pembelajaran berlangsung dengan efektif, guru harus mampu menyediakan bahan ajar yang sesuai dengan kebutuhan dan media pembelajaran yang dapat membantu menyampaikan materi serta keterampilan kepada siswa.

Media pembelajaran yang kekinian lebih dapat diterima sehingga siswa memiliki keinginan untuk mempelajarinya. Pembelajaran perlu menyesuaikan dengan keadaan terkini (Syafiudin, Sumarmi, \& Astina, 2016). Media pembelajaran yang kekinian juga dapat diciptakan dari melihat lingkungan sekitar. Lingkungan pembelajaran yang menyenangkan bisa diciptakan dari pembelajaran berbasis internet. (Rahayu, Pratikto, \& Rahayu, 2016) menyatakan bahwa, "contoh yang terjadi langsung di dalam dunia nyata yang terjadi di sekitar siswa agar cepat memahami materi". Upaya agar siswa aktif dalam pembelajaran dapat dilakukan dengan menciptakan lingkungan pembelajaran yang kontekstual. Lingkungan yang menyenangkan menjadikan siswa senang untuk belajar.

Media dapat memenuhi kebutuhan dan karakteristik siswa sebagai perantara pesan dari konkret ke abstrak. Kemampuan berpikir siswa yang masih dalam tahap operasional konkret menurut Piaget dimana siswa membangun konsep pengetahuan melalui benda konkret (Ali \& Asrori, 2010). Alat atau bahan untuk pembelajaran dapat membantu guru ketika memberikan informasi, memunculkan perhatian, pikiran, rasa dan keinginan siswa untuk belajar. Peran guru dalam pembelajaran dengan media yaitu memfasilitasi dan membimbing siswa sangat dituntut dalam memaksimalkan pembelajaran. 
Penggunaan media berbasis teknologi diharapkan dapat menjalin komunikasi yang intensif antara siswa dengan guru. Internet merupakan merupakan hasil kemajuan teknologi yang banyak digunakan saat ini dan bisa mendukung dalam pembelajaran (Cholid, Elmunsyah, \& Patmanthara, 2016). Hal ini disebabkan teknologi tersebut telah terbukti mampu memberikan kontribusi bagi siswa dalam aktivitas pembelajaran mereka. Produk teknologi untuk keperluan pendidikan yang banyak diteliti oleh para ahli merupakan dasar pengembangan media ini. Media pembelajaran peta berbasis web adalah produk dari pengembangan teknologi komunikasi dan pembelajaran jejaring sosial.

Media pembelajaran peta berbasis web yang dikembangkan setelah melewati tahap validasi kepada para ahli dan tanggapan siswa. Setelah tahap validasi diperoleh beberapa saran yang dijadikan pengembang sebagai acuan untuk memperbaiki produk media yang dibuat sebelumnya. Beberapa saran yang sesuai dengan tujuan pengembangan media peta berbasis web adalah dengan memperbaiki peta, memadatkan materi dan menonjolkan gambar agar dapat lebih diterima siswa.

Pengembangan media peta berbasis web ini juga merupakan salah satu bentuk dari pemanfaatan IPTEK yang semakin berkembang pesat. Media dimanfaatkan dalam pembelajaran mata pelajaran geografi. Berdasarkan hasil validasi pada para ahli dan uji coba pada siswa, hasil akhir dari pengembangan ini adalah berupa media pembelajaran berbasis web, yakni berbagai peta Banyuwangi yang berisi tentang berbagai materi Geografi kelas XI yang terintegrasi pada kabupaten Banyuwangi. Media pembelajaran peta berbasis web ini efektif digunakan untuk siswa. Hal tersebut dikarenakan hasil keefektifan media yang telah diuji di dua sekolah. Media ini dapat memfasilitasi siswa dengan sesuai kecepatan belajar siswa masing-masing.

Hasil analisis dari angket siswa dan juga guru, menunjukkan bahwa media pembelajaran peta berbasis web mampu menarik dan memberikan variasi berbeda dalam pembelajaran. Secara umum, siswa terlihat tertarik dan antusias saat menggunakan media tersebut. Terlebih media juga menampilkan kegiatan peta-peta, video, dan gambar. Apalagi pada materi geografi kelas xi masih kurang banyak media peta kontekstual yang bisa dipakai dan dimanfaatkan oleh siswa maupun guru. Oleh karena itu, media berbasis web ini dapat menjadi sumber atau sarana yang efektif dalam pembelajaran Geografi baik di kelas maupun secara mandiri.

Tema ini peneliti masukkan dalam materi Geografi kelas XI. Peta berbasis aplikasi web yang dikembangkan ini disesuaikan dengan analisis kondisi belajar siswa kelas XI IPS di SMAN 1 Srono dan SMAN 1 Cluring. Salah satu komponen pembelajaran berupa media peta berbasis web. Media berisi peta, gambar yang dapat menjelaskan objek, dapat membantu siswa dalam memahami materi yang ada. Hal ini didukung pendapat Lee dan Owens (2004) yang mengemukakan bahwa, "pada prinsipnya aplikasi media, siswa akan belajar ketika menggunakan contoh nyata dan menggunakan ilustrasi yang digunakan untuk mendemonstrasikan konsep dan keterampilan pada saat siswa belajar". Pentingnya pembelajaran yang menggunakan lingkungan sekitar sebagai contoh dari materi Geografi. Berikut disajikan pada gambar 1 dan 2 mengenai identitas produk dan gambar sebelum dan sesudah revisi. Identitas produk atau media peta berbasis web, meliputi (a) Bentuk: website, (b) Alamat web: petageo11.web.id, (c) Sasaran: siswa kelas XI IPS SMA di Banyuwangi, dan (d) Software aplikasi: xammp dan wordpress.

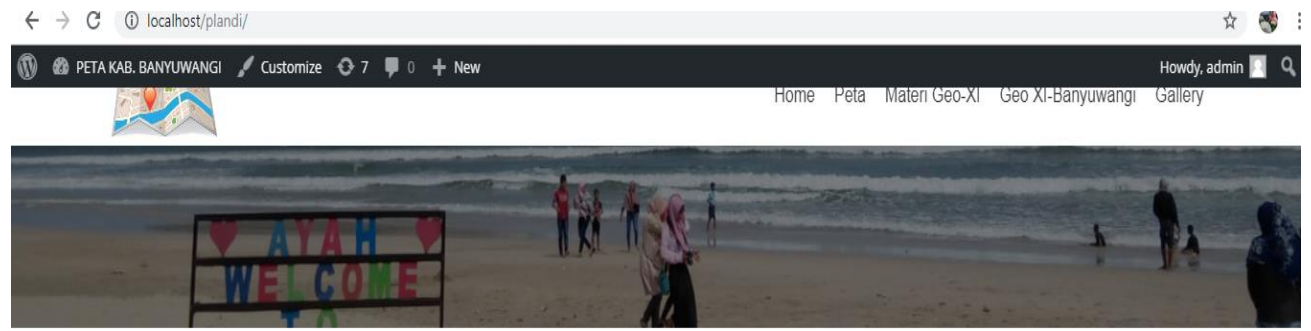

\title{
PETA BANYUWANGI
}

\author{
MEDIA PEMBELLAJARAN GEOGRAFI KELAS XI
}
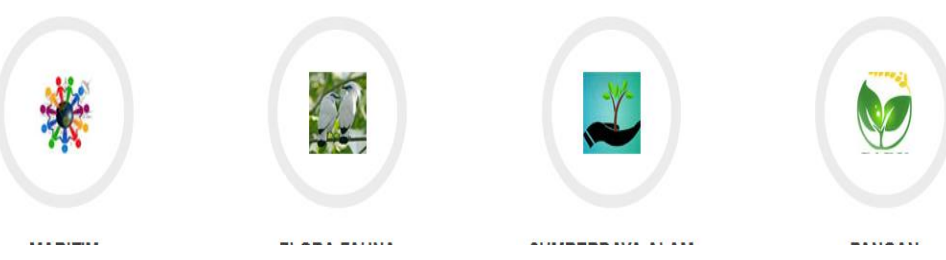

Gambar 1. Hasil Produk Sebelum Revisi 


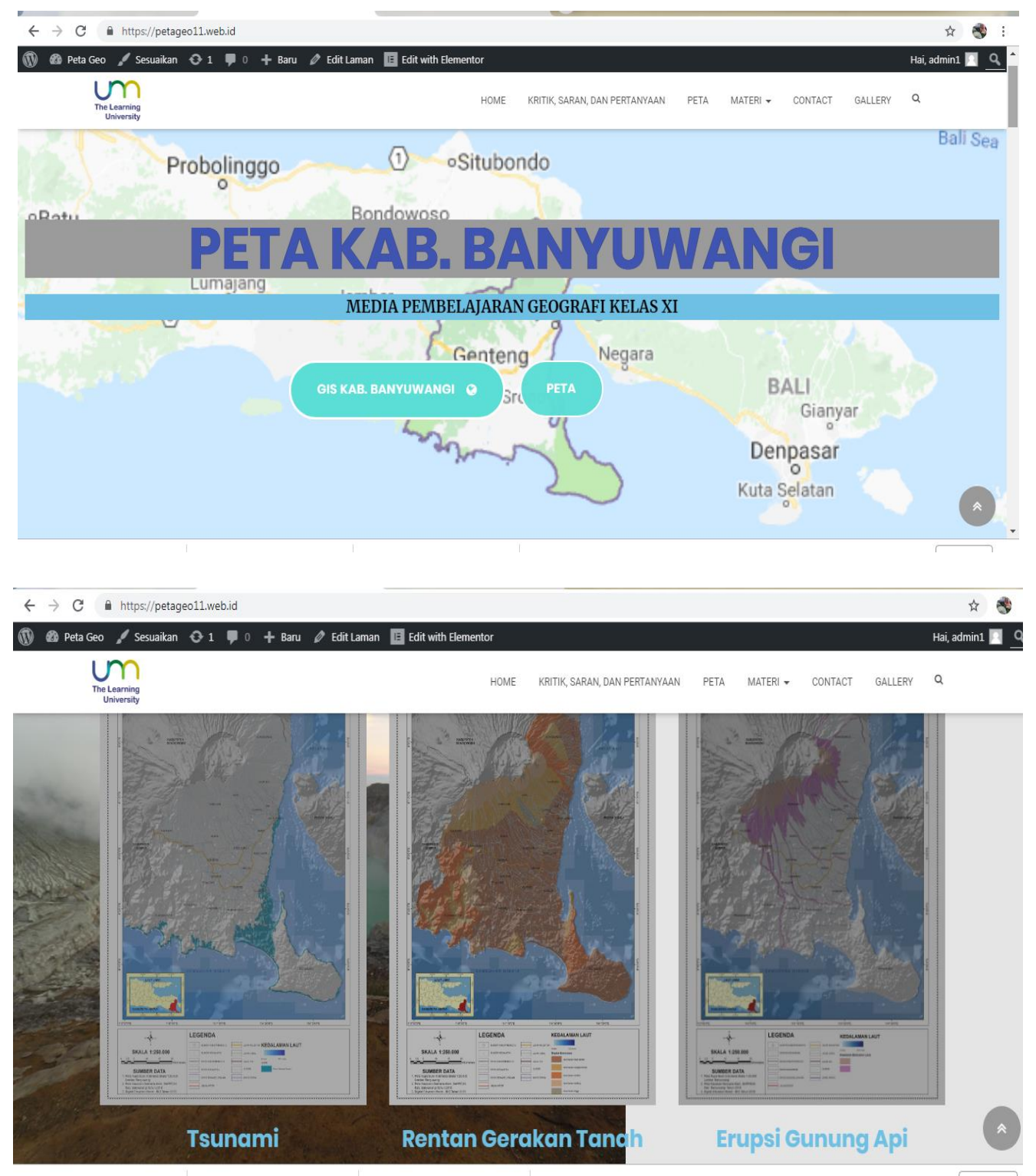

Gambar 2. Hasil Produk Sesudah Revisi

Berdasarkan hasil dan pembahasan yang telah diuraikan, maka media peta berbasis web efektif dan manfaat media pembelajaran dapat dilihat dari angket atau tanggapan siswa maupun guru pada saat digunakan. Kebermanfaatan media pembelajaran ditinjau dari berbagai aspek, meliputi aspek tampilan, materi, penggunaan, dan lainnya. Maka dari itu, media pembelajaran yang baik harus dapat memenuhi kriteria efektif dan sesuai dengan kebutuhan siswa.

\section{SIMPULAN}

Berdasarkan hasil analisis dan pembahasan pada bab sebelumnya dapat disimpulkan bahwa media pembelajaran peta berbasis web adalah produk penelitian pengembangan dengan menggunakan model ADDIE (Analysis, Design, Development, and Evaluation) yang dijalankan atau diakses menggunakan jaringan internet. Produk yang sudah didesain atau produk setengah jadi kemudian divalidasi untuk menentukan kevalidan atau kelayakan sebelum diuji coba. Produk ini divalidasi oleh ahli media. Hasil analisis uji coba lapangan dilakukan untuk menilai keefektifan produk sebelum digunakan secara luas. Hasil uji coba oleh guru diperoleh persentase 83,33\%, nilai diperoleh dari presentasi sebesar 50 dari 60 nilai maksimal. Hasil analisis uji coba lapangan oleh siswa diperoleh persentase $80 \%$, yang diperoleh dari persentase skor 32 dari skor maksimalnya 40. Hasil uji coba oleh guru dan siswa tersebut dinyatakan efektif untuk digunakan secara luas. Berdasarkan hasil uji coba bahwa media ini dapat digunakan sebagai media pembelajaran Geografi kelas XI untuk menunjang pembelajaran sehingga siswa lebih memahami materi Geografi. 


\section{DAFTAR RUJUKAN}

Ali, M., \& Asrori, M. (2010). Psikologi Remaja: Perkembangan Peserta Didik. Jakarta: Bumi Aksara. Arsyad, A. (2013). Media Pembelajaran. Jakarta: Rajawali Pers.

Cholid, A. A., Elmunsyah, H., \& Patmanthara, S. (2016). Pengembangan Model Web Based Learning pada Mata Pelajaran Jaringan Dasar Paket Keahlian TKJ pada SMKN Se-Kota Malang. Jurnal Pendidikan: Teori, Penelitian, dan Pengembangan, 1(5), 961-970.

Evendy, R., Sumarmi, \& Astina, I. K. (2018). Pengembangan Lembar Kerja Siswa Berbasis Kontekstual pada Materi Kearifan dalam Pemanfaatan Sumber Daya Alam. Jurnal Pendidikan: Teori, Penelitian, dan Pengembangan, 3(2), 271-277.

Nadlah, I. (2011). Penerapan Media Pembelajaran Bervariasi dapat Meningkatkan Kualitas Pembelajaran Materi Saling Ketergantungan dalam Ekosistem pada Siswa Kelas VIID SMPN 40 Semarang. Jurnal Penelitian Pendidikan, 28(1), 4853.

Putri, C., Corebima, A. D., \& Lestari, S. R. (2016). Pengembangan Media Pembelajaran menggunakan Aplikasi Berbasis Web pada Materi Biologi Semester Genap untuk Siswa Kelas XI SMA Negeri 1 Batu. Jurnal Pendidikan Hayati, 1-6.

Rahayu, D., Pratikto, H., \& Rahayu, W. P. (2016). Pengembangan Modul Pembelajaran Kontekstual Bermuatan Karakter pada Mata Pelajaran Kewirausahaan di SMK Cendika Bangsa Kepanjen. Jurnal Pendidikan Bisnis dan Manajemen, 2(3), 225232.

Rahmawati, I. S., Roekhan, \& Nurchasanah. (2016). Pengembangan Media Pembelajaran Menulis Teks Fabel dengan Macromedia Flash bagi Siswa SMP. Jurnal Pendidikan: Teori, Penelitian, dan Pengembangan, 1(7), 1323-1329.

Sari, H. V., \& Suswanto, H. (2017). Pengembangan Media Pembelajaran Berbasis Web untuk Mengukur Hasil Komputer Jaringan Dasar Program Keahlian Teknik Komputer dan Jaringan. Jurnal Penelitian: Teori, Penelitian, dan Pengembangan, 2(7), 1008-1016.

Sulfiah, U., \& Sulisworo, D. (2016). Pengembangan Media Pembelajaran Kontekstual menggunakan Komik Fisika untuk Peserta Didik SMP/MTs Kelas VII pada Pokok Bahasan Kalor. Jurnal Berkala Fisika Indonesia, 8(2), 31-37.

Suryani, N. (2016). Pengembangan Media Pembelajaran Sejarah Berbasis IT. Jurnal Sejarah dan Budaya, 10(2), 186-196.

Syafiudin, M., Sumarmi., \& Astina, I. K. (2016). Pengembangan Modul Geografi Pariwisata dengan Project Based Learning untuk Materi Ekowisata Pesisir dan Laut di Program Studi S1 Pendidikan Geografi Universitas Negeri Malang. Jurnal Pendidikan: Teori, Penelitian, dan Pengembangan, 1(3), 347-353.

Utomo, D. H. (2015). Pengembangan Bahan Ajar Meteorologi-Klimatologi Berdasarkan Brain Based Learning. Universitas Negeri Malang.

Wahyuningsih, D., \& Budiningsih, C. A. (2014). Implementasi Blended Learning By The Constructive Approach (BLCA) dalam Pembelajaran Interaksi Manusia dan Komputer. Jurnal Inovasi Teknologi Pendidikan, 1(1), 15-27. DOI: https://doi.org/10.21831/tp.v1i1.2456

Widiyaningtyas, T., \& Widiatmoko, A. (2014). Media Pembelajaran Berbasis Web pada Mata Pelajaran Kimia. Jurnal Teknologi, 21, 47-51.

Yusuf, H., Yarmaidi., \& Miswar, D. (2015). Pemetaan Objek Wisata Alam Kabupaten Pesisir Barat Tahun 2015. Jurnal Penelitian Geografi, 3(2), 1-10. 